\title{
Evaluation Model of the Management Zakat Profession of the State Civil Apparatus (ASN) by the National Amil Zakat Agency (BAZNAS) of Bandung
}

\author{
Maya Kusuma Permata Sari ${ }^{1}$, Didin Muhafidin ${ }^{2}$, R. Achmad Buchori ${ }^{3}$ \\ ${ }_{1,2,3}$ Padjadjaran University, Bandung, Indonesia \\ email:mayakusuma@gmail.com
}

\begin{abstract}
This study aims to determine the evaluation model of zakat management for the civil servant by the National Amil Zakat Agency (BAZNAS) in the city of Bandung. Qualitative research methods used are needed data related to the evaluation of professional zakat management by using a set of open and flexible question lists from formulation of the problem regarding assessment of civil servant professional zakat management in the National Amil Zakat Agency (BAZNAS) of Bandung, to be explained, described, investigated and understood overall problem that occurs. The results showed that the evaluation model of zakat management of the Bandung City Civil Servants (ASN) profession was carried out by the Bandung City BAZNAS, as a planner, executor, and coordinator in the collection and utilization of zakat. The Zakat Collecting Unit (UPZ), whose task is to collect professional zakat from ASN, uses the Official Assessment system through salary deductions made by the Salary Treasurer. The process, benefits, and impacts relating to the pattern of receipt and distribution of professional zakat are carried out by delegating management authority and responsibility for the payment of the National Amil Zakat Agency (BAZNAS) and distributing professional zakat to the entitled parties, 8 Ashraf both consumptive and productive. in the form of venture capital.
\end{abstract}

Keywords: Managmenet Evaluation Model, Zakat Profession, Civil Servant (ASN), National Amil Zakat Agency (BAZNAS).

\section{A. INTRODUCTION}

Zakat is a social worship institution derived from Islamic legal terms (Shobirin, 2015), the term zakat will not be separated from the conception of zakat according to Islam, in which there is a mechanism for collecting zakat from the muzakki (people who give zakat) and the use of zakat for the mustahik (people who receive zakat). Zakat utilization is the most critical aspect of achieving the objectives of zakat collection, so an institution or body that is professional in managing and utilizing zakat funds is needed.

The government established the National Amil Zakat Agency (BAZNAS), which is authorized to carry out the task of managing zakat nationally. Law Number 23 of 2011 concerning Management of Zakat states that in the framework of implementing zakat management at the provincial and district/city levels, a provincial BAZNAS and district/city BAZNAS were formed. One of the zakat management institutions at the re- 
gency/city level is the formation of the National Board of Education in Bandung, which was previously named the Amil Zakat Agency (BAZ) of the City of Bandung.

This research was conducted by emphasizing the role of the Bandung National Amil Zakat Agency as the leading sector of zakat collection and distribution organizations in implementing the provisions of Bandung Mayor's Instructions No. 1 of 2017 concerning the Implementation of Professional Zakat, Infaq, and Shadaqoh for Bandung City Civil Servant. The professional zakat potential from the Bandung City Government ASN increased significantly to 2 billion Rupiah each month in 2016 after the Bandung Mayor Circular Letter (source: BAZNAS Bandung City, 2019).

Based on the results of preliminary data collection through interviews with the Head of the National Amil Zakat Board (BAZNAS) of Bandung City, issues related to the management of the ASN professional zakat experienced include reporting on the results of the management of Zakat, Infaq and Sadaqah both as a whole and reporting on the results of the collection of ASN professional zakat collection structured and detailed, the Bandung City BAZNAS cannot show even the search results of the Bandung City BAZNAS Annual Performance Report Book, the strategy of management of ASN zakat is not yet optimal in its distribution context, there has been no apparent change in program creativity in seeing conditions before and after the mandatory ASN zakat.

This research, considering the results of previous studies relating to the development of understanding in the practice of evaluation conducted by Schoenefeld and Jordan (2017) which concludes that typology is useful to guide new thinking, by highlighting essential gaps in empirical knowledge about various models of evaluation of the implementation of an activity, with identifying the need for a new research agenda that simultaneously develops a more complete understanding of evaluation practices and options for managing it.

Other research was conducted by Maggetti and Gilardi (2016), who put forward the conceptual structure of evaluation that serves as a guide for the application of diffusion arguments, a starting point for theoretical refinement and benchmarks for assessing the validity of measurements, by paying more attention to the conceptual consistency of indicators, addressing the problems currently found in the literature requires the construction of innovative research designs.

Also, other research conducted by Husna (2018) concluded that the implementation of infaq and shadaqah zakat management was not optimal because the zakat collection unit could not control the business conditions, because there was no supervision system established by the Amil Zakat Agency in Siak Regency. The results of this study are different from the effects of research conducted by Ancas (2015), which concluded that overall the mustahik assesses the productive zakat program by Baznas has been going very well.

Zakat, which is intended for mustahik, can be used as business capital where businesses developed by mustahik are generally small scale, which is not accessed by 
bank financial institutions. The assistance process that is implemented includes planning, implementing, monitoring and controlling and evaluating the program, becoming one of the plans of the amil zakat body in managing productive zakat, so that it is expected to create economic circulation, increase the productivity of community businesses, increase income/results economically, and sustainable (sustainable).

Other studies relating to the management of the civil servant profession zakat in MAN Wonosari both from the collection and distribution of mustahiq are done professionally, evidenced by an increase in zakat payers and the broad reach of mustahiq (Ngadiyan, 2017).

\section{B. RESEARCH METHODS}

This study uses qualitative research methods, a method to explore and understand the meaning of several individuals or groups of people who are considered to originate from social or humanitarian problems (Creswell, 2010: 4). This qualitative research method is used because it requires data related to the evaluation of zakat management of the Civil Servant (ASN) at the National Amil Zakat Agency (BAZNAS) of Bandung City

Qualitative research is a type of study in which the researcher is very dependent on information from objects/participants in a broad scope, general questions, data collection which consists mainly of words/texts from participants, explain and analyze concepts and conduct research subjectively (Creswell, 2008: 46).

The strategy to be applied in this research is a case study that, according to Creswell (2010: 20), is a research strategy in which researchers investigate a program, event, activity, process, or group of individuals carefully. The cases are limited by time and business, to collect detailed information using a variety of data collection procedures.

Interview guide with a set of questions that are open and flexible based on the formulation of the problem regarding the evaluation model of ASN profession zakat management in the National Amil Zakat Board (BAZNAS) of Bandung City, as well as knowing the mechanism in evaluating zakat management, to be explained, described, investigated and understood thoroughly for the problem that occurred.

\section{RESULTS AND DISCUSSION}

There are problems related to the implementation of the management of the Civil Servant Zakat (ASN) as a public administration related to the implementation of the implementation of zakat management activities by BAZNAS in Bandung. The management of the zakat for the profession of the Civil Servant (ASN) of Bandung City in the planning, implementation, and coordination of activities in the collection, distribution, and utilization of the zakat of the ASN profession by the Bandung City BAZNAS.

A program is not just a single activity that can be completed in a short time, but it is a continuous activity because it implements a policy. All programs need to be evaluated to 
determine whether the service or intervention has met the stated objectives. Program evaluation is a systematic method for gathering, analyzing, and using the information to answer basic questions about the program. While the evaluator is the person who evaluates. Many evaluation criteria, types, or models are used as strategies or work guidelines in implementing program evaluation. Evert Vedung (2009: 9) put forward four principles in program evaluation as follows:

1. Effective

2. Productivity

3. Efficiency (cost-benefit)

4. Efficiency (cost-effectiveness) Hamalik (2005:17) argues that the model or type of program evaluation is as follows:

1. Assessment of planning and development. The main goal is to assist programmers by providing the information needed to design a program. Evaluation results can be used to predict the implementation of the program and the possibility of achieving the program in the future.

2. Evaluate monitoring is carried out to check whether the program reaches its useful target. Are the things and activities that have been completed explicitly in the program carried out correctly. The fact is not uncommon that the program actually does not reach the target.

3. Impact evaluation, aims to assess how far the program program can have a specific effect on the targets set, whether the program has a positive impact or just the opposite. The result is measured based on success criteria, so the application needs to be specified so that it can be observed and measured after the program is implemented.

4. Evaluation of efficiency, intended to assess how much the level of effectiveness of a program. Is the program able to provide benefits.

5. Evaluation of comprehensive programs, namely the overall impact on the program, which includes; program implementation, effect, or influence after the application is implemented and the level of program efficiency.

Furthermore, Wirawan (2012:17), groups program evaluations into three different parts, namely:

1. Process evaluation which examines and assesses whether program interventions or services have been implemented as planned, and whether the scheduled target population has been served;

2. The benefits evaluation (outcome evaluation) examines, evaluates and determines whether the program has produced the expected changes;

3. Impact evaluation (impact evaluation), which sees the differences caused before and after the application.

In this study, researchers present information using evaluation groupings, namely process evaluation, benefits evaluation, and impact evaluation was to see and assess the implementation of ASN Zakat Management valued from the process, benefits and impacts. Accord- 
ing to Wirawan (2012: 17), part of the process evaluation (process evaluation) can be used to assess the implementation of a program service, where the application or execution of a program will be seen from the whole process or series of activities that have been carried out. Process evaluation is carried out by evaluating the information obtained, by seeing whether the program services have been implemented as planned, the information is then analyzed and can be presented with qualitative data. Evaluate benefits, examine, assess, and determine whether the program has produced the expected changes. And impact evaluation, evaluate whether the expected change has affected.

From Wirawan's explanation above, the writer concludes that the evaluation will be carried out in several stages of assessment, namely:

1. The first stage, measurement or assessment can be done by comparing the results against the reality in the field;

2. The second stage, the comparison that has been obtained is then concluded and qualified by the objectives of the assessment to be achieved from the evaluation;

3. The third stage, examine and assess the results of the review whether it has provided the expected benefits;

4. The fourth stage, determine whether the benefits affect the implementation of the program.

Based on this information, the evaluation model in the Management of Zakat ASN in this study is carried out by the existing stages, so that the evaluation goal is achieved. The following are the results of the research in the form of an evaluation model for the management of the Zakat of the civil servant (ASN). 


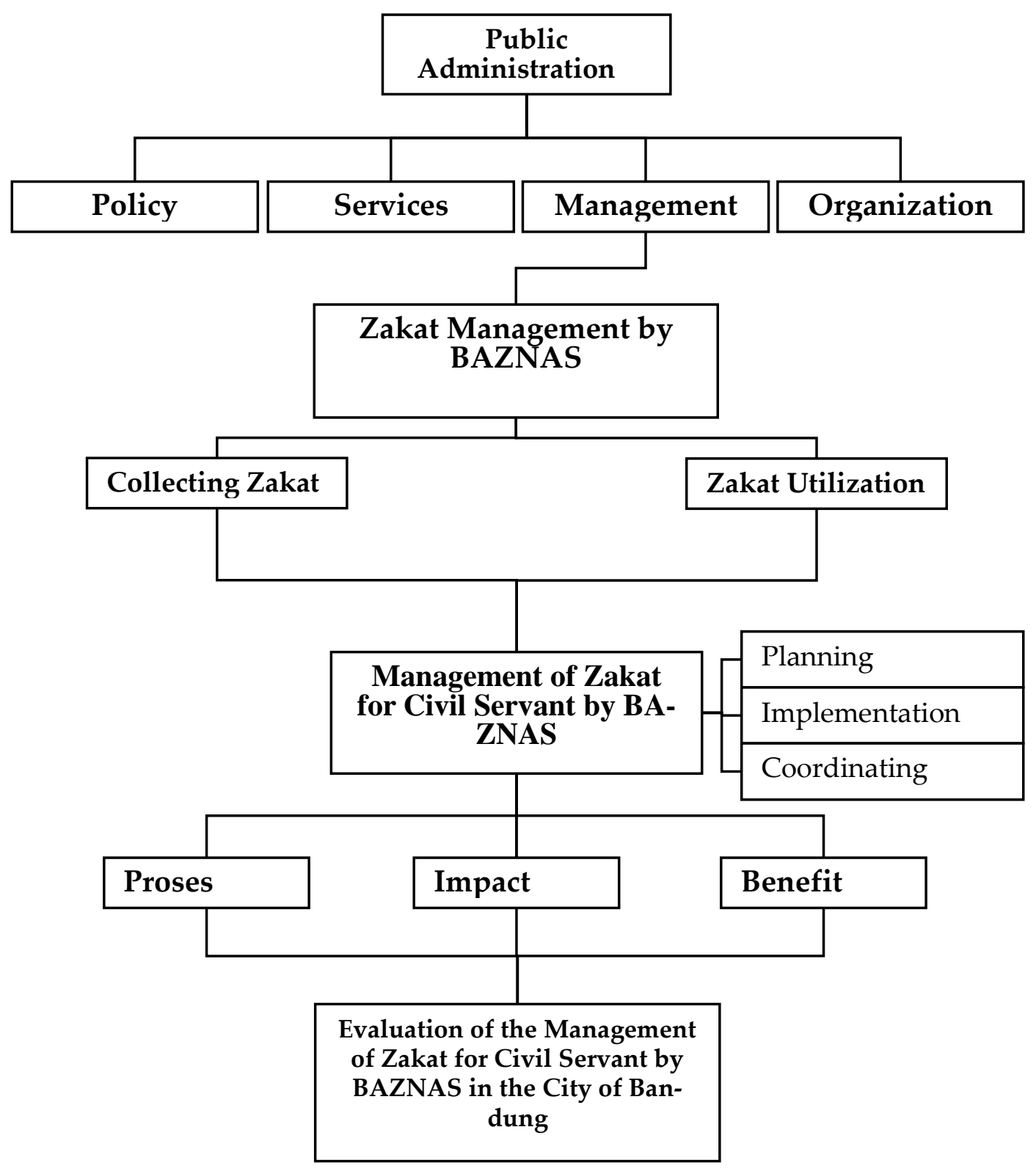

Picture 1 Evaluation Model of the Management of the Civil Servant (ASN) by the National Amil Zakat Agency (BAZNAS) of Bandung City

\section{CONCLUSION}

Professional alms in Islam are essentially zakat issued from the results of one's profession (work), whether doctors, lecturers, teachers, principals, employees, etc. whose salaries are paid by the government, and have enough Nisab to be distributed to the mustahiq zakat. The results showed that the evaluation model of zakat management of the Bandung City Civil Servants (ASN) profession was carried out by the Bandung City BAZNAS, as planners, executors, and coordinators in the collection and utilization 
of zakat. The Zakat Collecting Unit (UPZ), whose task is to collect professional zakat from ASN, uses the Official Assessment system through salary deductions made by the Salary Treasurer. The process, benefits, and impacts relating to the pattern of receipt and distribution of professional zakat are carried out by delegating management authority and responsibility for the payment of the National Amil Zakat Board (BAZNAS) and distributing professional zakat to the entitled parties, 8 ashnaf both consumptive and productive in the form of venture capital.

\section{REFERENCES}

1. Cresswell, J. W. (2008). Educational Research, Planning, Conducting, and Evaluating Qualitative and Quantitative Approaches. London: Sage Publication.

2. Creswell, J. W. (2010). Research Design: Pendekatan Kualitatif, Kuantitatif, dan Mixed. Yogjakarta: Pustaka Pelajar..

3. Hamalik, O. (2002). Pendidikan Guru Berdasarkan Pendekatan Kompetensi. Jakarta: Bumi Aksara.

4. Vedung, E. (2009). Public Policy and Program Evaluation. New Jersey: Transaction Publishers.

5. Wirawan. (2012). Evaluasi Teori, Model, Standar, Aplikasi dan Profesi. Jakarta: Rajawali Pers.

6. Pribadi, A. S. (2006). Pelaksanaan Pengelolaan Zakat Menurut Undang-undang Nomor 38 Tahun 1999 tentang Pengelolaan Zakat (Universitas Diponegoro Semarang). Kenotariatan, 86:1-8.

7. Schoenefeld, J., \& Jordan, A. (2017). Governing policy evaluation? Towards a new typology. Institute of Political Science, Technische Universität Darmstadt, Germany, and Tyndall Centre for Climate Change Research, School of Environmental Sciences, University of East Anglia, UK, 23(3), 274-293.

8. Shobirin. (2015). Teknik Pengelolaan Zakat Profesi. Jurnal Zakat dan Wakaf ZISWAF, 2(2), 317-338.

9. Maggetti, M., \& Gilardi, F. (2016). Problems (and Solutions) in the Measurement of Policy Diffusion Mechanisms. Journal of Public Policy, 36(1), 87-107.

10. Husna, M. (2018). Implementasi Kebijakan Pengelolaan Zakat Produktif di Kecamatan Sungai Apit Kabupaten Siak. JOM FISIP, 5(I), 1-15.

11. Ngadiyan. (2017). Professionalisme Pengelolaan Zakat Profesi dalam Meningkatkan Motivasi Prestasi dan Berdikari Mustahiq: Studi Kasus Zakat Profesi ASN di MAN Wonosari. Jurnal Pendidikan Madrasah, 2(1), 23-36. 